\title{
Studies on Intercropping Soybean with Sugar cane under Different Nitrogen Levels
}

\author{
A.S.M. Morsy", A.M. Elwan* andNadia M.A.Eissa** \\ Department of Agronomy, Faculty of Agriculture \& Natural Resources, Aswan University, \\ Aswan 81528; "Sugar Crop Res. Inst, Agric. Res. Center and ${ }^{* *}$ Crop Intensification Res.Sec., \\ Field Crops Research Institute, Agric. Res. Center, Giza, Egypt.
}

\begin{abstract}
$\mathbf{T}$ WO experiments were conducted at Mallawy Agric. Res. Station, Minia Governorate, Egypt during 2014/2015 and 2015/2016 seasons to study the effect of intercropping soybean with sugar cane under different levels of $\mathrm{N}$ fertilizer. A split plot design with four replicates was used for both experiments. Main plots were devoted for N levels i.e.195, 210 and $225 \mathrm{~kg} \mathrm{fad}^{-1}$ of nitrogen. The intercropping patterns of soybean as $100 \%$ sugarcane $+30 \%$ soybean in one row, $100 \%$ sugarcane $+30 \%$ soybean in two rows, $100 \%$ sugarcane $+40 \%$ soybean in one row, $100 \%$ sugarcane $+40 \%$ soybean in two rows, pure stand of sugar cane and soybean were distributed in sub-plots.
\end{abstract}

Nitrogen levels had significant effect on most studied characters of soybean. Increasing $\mathrm{N}$ levels up to $225 \mathrm{~kg} \mathrm{fad}^{-1}$ increased all studied traits of yield and yield components of soybean. The highest values of yield and yield components were produced from pure stand compared to intercropping patterns. On the other hand, intercropping pattern of $100 \%$ sugar cane $+40 \%$ soybean in one row gave the highest seed yield. Increasing $\mathrm{N}$ level up to $225 \mathrm{~kg} \mathrm{fad}^{-1}$ caused significant differences on yield and its components of sugar cane as well as quality parameters and sugar yield fad ${ }^{-1}$. The highest sugar yield fad ${ }^{-1}$ was gained from $225 \mathrm{kgf} \mathrm{ad}^{-1}$ of nitrogen.

Intercropping patterns of soybean on sugar cane had a significant effect on studied characters of sugar cane. $100 \%$ sugar cane $+40 \%$ soybean in one row ( 2 plants hill $\left.{ }^{-1}\right)$ gave the highest values. In general, pure stand of sugar cane gave the highest values of juice quality and sugar yield fad $^{-1}$. The value of Land Equivalent Ratio (LER) is greater than one, which indicates the increasing land productivity per unit area. The highest value of LER (1.56) was obtained by intercropping $40 \%$ soybean in one row (2 plants hill-1) on $100 \%$ sugar cane with $225 \mathrm{~kg}$ $\mathrm{fad}^{-1}$. Aggressivity (Agg) values of sugar cane were positive dominant, while those of soybean were negative dominated intercropping $40 \%$ soybean on $100 \%$ sugar cane with $225 \mathrm{~kg} \mathrm{~N}^{-1}$. The actual yield loss (AYL) values for sugar cane and soybean were positive at all patterns intercropping. The highest values of total income and profit obtained from $100 \%$ sugar cane + $40 \%$ soybean in one row ( 2 plants hill-1) with $225 \mathrm{~kg} \mathrm{fad}^{-1}$ of nitrogen.

Keywords: Intercropping, N levels, Sugar cane, Soybean.

\section{Introduction}

The cultivated area in Egypt is limited, so the agriculture intensification becomes urgent necessity to optimize the utilizing of unite area. Intercropping is considered to be one of the most important tools of agriculture intensification, it is a way to achieve intensive utilization for both edaphic and climatic factors. Also, mixing crops leads to reduce the risk of failure (Sayed et al., 1983 and Abdel-Wahab \& Abd El-Rahman, 2016)

It is possibly to plant one of the legume crops intercropped with sugar cane, this leads to an increase in the total production, also it benefits the soils. Thus the basic question asked here is: what is the best systems of intercropping must be allowed to increase the total production (Rana et al., 2006)

\#Corresponding author: drahmed1122@yahoo.com

DOI : 10.21608/agro.2017.848.1061

C2017 National Information and Documentation Center (NIDOC) 
Sugar cane (Saccharum officinarum L.) is a long duration and widely spaced crop in comparison with other field crops, it offers a great scope for using its interspaces by growing short duration crops. In general, sugar cane has a juvenile period of 100-120 days, so that the intercrops of soybean and sugar cane are widely practiced. Sugar cane is generally planted in 80$100 \mathrm{~cm}$. ridges, and soybean could be intercropped on ridges of sugar cane at the same time (Abdul Rehman et al., 2014).

Assey et al. (1992) studied the effect of intercropping soybean, maize and nitrogen fertilizer levels on yield and yield attributes of soybean. Their results showed that soybean planted under intercropping possessing decreased in some characters, i.e., pod No. plant $^{-1}$, seed number plant ${ }^{-1}$, seed yield plant ${ }^{-1}$, seed index and seed yield $\mathrm{fad}^{-1}$.Otherwise, the $\mathrm{N}$ applications significantly increased the above-mentioned traits.

The intercropping of soybean with sugar cane exhibited that brix $\%$ and sucrose $\%$ in pure stand exhibited a positive and significant advantage over the various intercropping patterns, while juice purity was not affected.Yield of sugar cane and soybean attained a significant increase in pure stand over the intercropping soybean raised (L.E.R.), while, the intercropping two rows soybean decreased sugar cane yield significantly (El-Gergawy et al., 1995).

Abou-Kresha et al. (1997) reported that significant differences between intercropping systems of cane with soybean.Yields of cane and soybean were significantly reduced under intercropping compared with pure stand. Brix $\%$, sucrose $\%$ and sugar yield of the intercropped plants were significantly lower than that assessed of pure stand. The sugar cane crop depletes a considerable amount of nutrient from soil, but soybean in intercropping pattern increases productivity per unite area of land and enables the crops more effectively utilize nutrients and improve soil fertility and field ecological conditions (Tang et al., 2005). Intercropping soybean with sugar cane recorded higher the number of cane $\left(87830 \mathrm{ha}^{-}\right.$ $\left.{ }^{1}\right)$ than cane alone $\left(85910 \mathrm{ha}^{-1}\right)$ as a result of the seed yield of soybean $\left(1.5\right.$ tha $\left.^{-1}\right)$ and lower cost of production in soybean intercropping (Khandgave, 2010). The cultivation model of sugar cane intercropping with soybean offers opportunity for profitable utilization of available land, water, light and other natural resources, and it's played an important role in development of sugar cane crop in terms of economic benefit per unit area (Che Jiang-Lul et al., 2011). The population economic benefit under sugar cane / soybean intercropping was 3.2\%-26.3\% higher at lower than at higher nitrogen application level ( $\mathrm{Li}$ et al., 2011). Significant yield reduction in sugar cane was noted due to intercropping comparing to the growing sugar cane as a mono crop which made more economic sense than intercropping under different levels of nitrogen (Ramouthar et al., 2013). Xiuping et al. (2013) showed that yield of sugar cane under sugar cane/soybean intercropping was increased by $30.57 \%$ and decreased by $16.12 \%$ for 100 -grain weight for soybean. Abdul Rehman et al. (2014) found cane diameter, stripped cane yield and cane growth rate was significantly higher in sole sugar cane when compared with different intercrop. Moreover, the intercrops gave higher land equivalent ratio (LER) and net return over sole sugar cane planted, while sole sugar cane gave the maximum benefit cost ratio compared with other intercrop. Yang et al. (2015) showed that the stalk diameter, cane yield and sugar production were significantly affected by sugar cane-soybean intercropping, while the cane quality was not change obviously compared with mono culture of sugar cane. Also, Khippal et al. (2016) observed that the intercropping trials have proved conclusively that crops like pea, chickpea and lentil can be successfully intercropping with autumn planted sugar cane for higher returns to the farmers with better cane quality and improving soil health for sustainable crop production.

The aim of the current investigation was to study the effect of various intercropping patterns of soybean on productivity and quality of sugar cane under different levels of nitrogen.

\section{Materials and Methods}

Two field experiments were conducted at Malawi Agric. Res. Station, Minia Governorate, Egypt during 2014/2015 and 2015/2016 seasons. The variety G.T.45-9 of sugar cane and Giza 35 of soybean were used for the present study. A split plot design with four replicates was used for both experiments. Main plots were occupied by three nitrogen fertilizer, i.e. 195, 210 and $225 \mathrm{~kg}$ $\mathrm{N} \mathrm{fad}{ }^{-1}$, while sub-plots allocated to the following intercropping patterns: \{the treatments were shown in Fig. 1\}. 


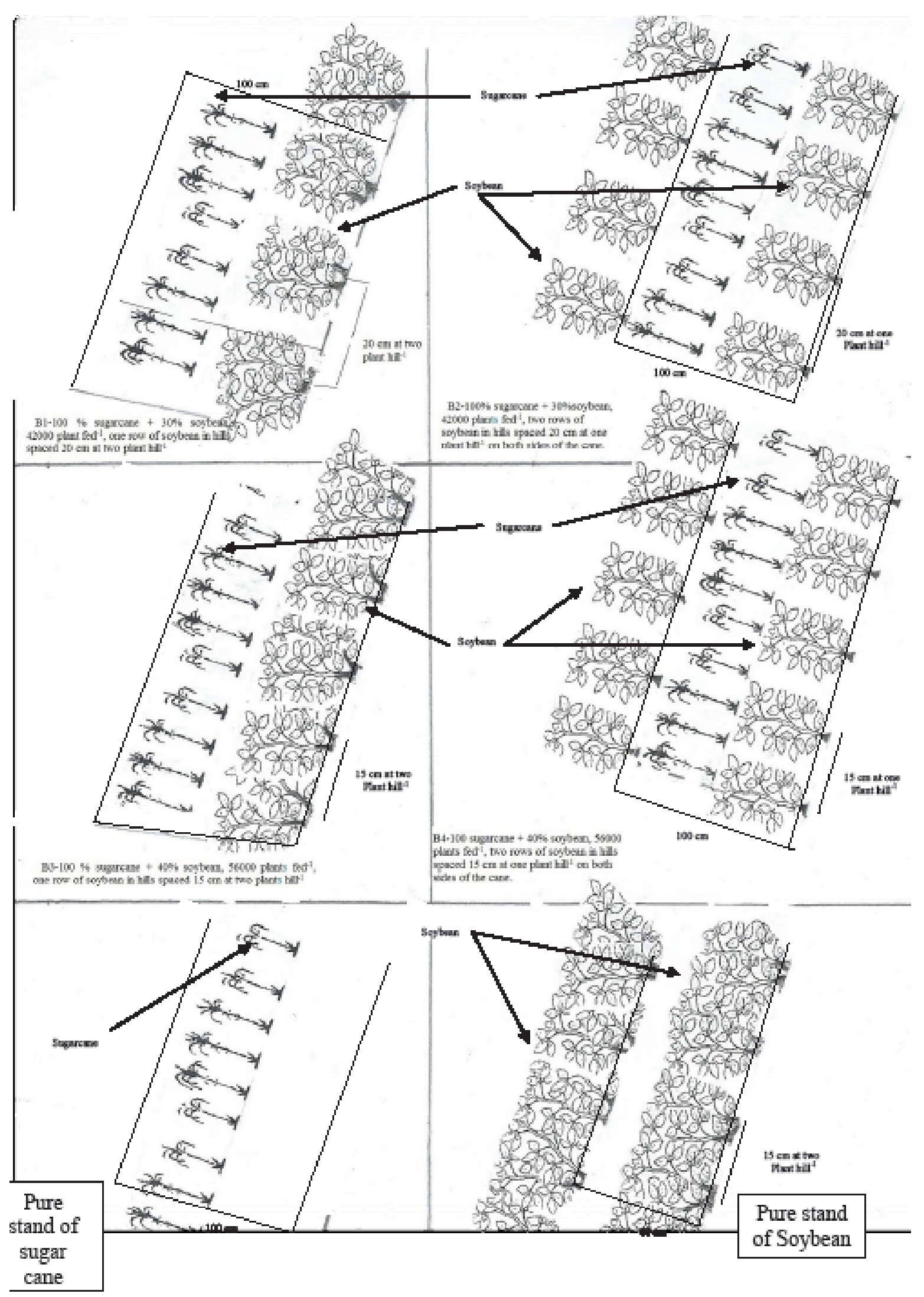

Fig .1. Intercropping soybean with sugar cane and sole culture of both crops. 
B1-100 \% sugar cane $+30 \%$ soybean, 42000 plants $\mathrm{fad}^{-1}$, one row of soybean in hills spaced 20 $\mathrm{cm}$ at two plants hill ${ }^{-1}$.

B2-100\% sugar cane $+30 \%$ soybean, 42000 plant $\mathrm{fad}^{-1}$, two rows of soybean in hills spaced $20 \mathrm{~cm}$ at one plant hill ${ }^{-1}$ on both sides of the cane.

B3-100 \% sugar cane $+40 \%$ soybean, 56000 plant $\mathrm{fad}^{-1}$, one row of soybean in hills spaced 15 $\mathrm{cm}$ at two plants hill ${ }^{-1}$.
B4-100 sugar cane $+40 \%$ soybean, 56000 plant $\mathrm{fad}^{-1}$, two rows of soybean in hills spaced $15 \mathrm{~cm}$ at one plant hill-1 ${ }^{-1}$ on both sides of the cane.

Added sole or pure stand of sugar cane and soybean (140000 plants fad $^{-1}$ of soybean). Figure 1 illustrates the intercropping soybean with sugar cane and sole culture of both crops. The timetable of sowing and cutting or harvesting dates for both crops are presenting in Table 1.

TABLE 1. Sowing and harvesting dates of sugar cane and soybean crops during 2014/2015 and 2015/2016 seasons.

\begin{tabular}{lcc}
\hline Crop & Sowing date & Harvesting or cutting date \\
\hline & $\mathbf{2 0 1 4 / 2 0 1 5}$ season & \\
Sugar cane & $1 / 3 / 2014$ & $28 / 2 / 2015$ \\
Soybean & $2 / 4 / 2014$ & $10 / 7 / 2014$ \\
& $\mathbf{2 0 1 5 / 2 0 1 6}$ season & \\
Sugar cane & $5 / 3 / 2015$ & $4 / 3 / 2016$ \\
Soybean & $5 / 4 / 2015$ & $13 / 7 / 2015$ \\
\hline
\end{tabular}

The physical and chemical analysis of the experimental site (according to Klute 1986) Table 2.

The plot area was $25 \mathrm{~m}^{2}$, consisted of five ridges, five meters length and one meter width. Phosphorus was added during soil preparation at rate of $150 \mathrm{~kg} \mathrm{fad}^{-1}$ calcium super phosphate $\left(15.5 \% \mathrm{P}_{2} \mathrm{O}_{5}\right)$, while potassium was applied at

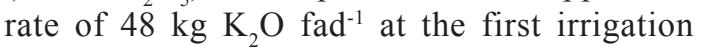
of sugar cane. Nitrogen fertilizer was applied as ammonium nitrate $(33.5 \% \mathrm{~N})$ in three equal doses just on sugar cane, second on sugar cane and soybean and third on sugar cane after harvest soybean. All the required agricultural practices were done as followed by sugar cane and soybean growers in the region.

\section{The recorded data \\ Soybean}

At harvesting time after 99 days from sowing, 20 guarded plants of soybean were taken randomly from each sub-plot to estimate: plant height (cm.), No. of branches plant ${ }^{-1}$, No. of pods plant ${ }^{-1}$, pod length $(\mathrm{cm})$, No. of seeds pod $^{-1}, 100$-seed weight $(\mathrm{gm})$, seed yield plant ${ }^{-1}$ (gm) and seed yield $\mathrm{kg} \mathrm{fad}^{-1}$.
Sugar cane

At cuttingdate after 12 month from sowing, 20 guarded stalks of sugar cane were taken from each sub-plots to determine the stalk height $(\mathrm{cm}$.)(it was measured from soil surface to the top dewlap), stalk diameter (cm), No. of internodes stalk ${ }^{-1}$, stalk weight $(\mathrm{kg})$, cane yield (ton $\mathrm{fad}^{-1}$ ), total soluble solids (TSS \%), which was determined using "Brix hydrometer" as shown by A.O.A.C. (2005), sucrose \% which was estimated according to A.O.A.C. (2005), juice puritywas determined according to Satisha et al. (1996) using the following equation: purity $\%=$ sucrose $\%$ X $100 /$ TSS $\%$, pol $\%$ of cane juice, was calculated by using the following equation : pol $\%=[$ Brix $\%$ (Brix \% - sucrose \%) 0.4] 0.73, reducing sugar of cane juice according to A.O.A.C. (2005), sugar recovery \% was calculated by using the following equation according to the procedures used by the sugar and Integrated Industry Company as sugar recovery $\%=[$ pol $\%-0.8 /$ purity $\%$ x purity $\%-40 / 100-60) 100$, and sugar yield (ton $\mathrm{fad}^{-1}$ ) according to the following equation: sugar yield (ton $\left.\mathrm{fad}^{-1}\right)=$ cane yield fad $^{-1} \times$ sugar recovery $\%$ according to Mathur (1981). 
TABLE 2. Chemical properties of Mallwai site in 2014/2015 and 2015/2016 seasons before planting the experiment.

\begin{tabular}{|c|c|c|}
\hline $\begin{array}{l}\text { Analysis } \\
\text { Texture analysis }\end{array}$ & $1^{\text {st }}$ Season & $2^{\text {nd }}$ Season \\
\hline Sand \% & 8.30 & 7.75 \\
\hline Silt \% & 53.40 & 53.70 \\
\hline Clay $\%$ & 38.30 & 38.55 \\
\hline Soil texture & Silty clay loam & Silty clay loam \\
\hline Organic matter $\%$ & 1.14 & 1.16 \\
\hline pH soil-water suspension ratio $(1: 2.5)$ & 8.25 & 8.15 \\
\hline \multicolumn{3}{|c|}{ Soluble cations ( meq/L ) } \\
\hline $\mathrm{Ca}^{++}(\mathrm{meq} / \mathrm{L})$ & 7.25 & 7.45 \\
\hline $\mathrm{Mg}^{++}(\mathrm{meq} / \mathrm{L})$ & 2.32 & 2.15 \\
\hline $\mathrm{Na}^{++}(\mathrm{meq} / \mathrm{L})$ & 3.30 & 3.22 \\
\hline $\mathrm{K}^{+}(\mathrm{meq} / \mathrm{L})$ & 0.18 & 0.20 \\
\hline \multicolumn{3}{|c|}{ Soluble cations ( meq/L ) } \\
\hline Co $(\mathrm{meq} / \mathrm{L})$ & - & - \\
\hline $\mathrm{HCO}(\mathrm{meq} / \mathrm{L})$ & 3.30 & 3.45 \\
\hline CL $($ meq/L $)$ & 4.25 & 4.15 \\
\hline $\mathrm{So}_{4}(\mathrm{meq} / \mathrm{L})$ & 5.40 & 5.42 \\
\hline Available N (ppm) & 18.15 & 18.25 \\
\hline Available P (ppm) & 7.76 & 7.58 \\
\hline Available K (ppm) & 155 & 156 \\
\hline
\end{tabular}

Competitive relationship and yield advantage

The following parameters were caculated:

Land Equivalent Ratio (LER): was calculated according to Willey (1979) by the following formula:

$$
\mathrm{LER}=\frac{y a b}{y a a}+\frac{y b a}{y b b}
$$

where: yaa=pure stand yield of a (sugar cane) $\mathrm{ybb}=$ pure stand yield of $\mathrm{b}$ (soybean). $\mathrm{yab}=$ yield of intercrop a (sugar cane) with $\mathrm{b}$ (soybean).

yba=yield of intercrop b (soybean with a sugar cane).
Aggressivity (Agg): This was proposed by McGilchrist (1965) and was calculated according to by the following formula:

Agab $=\frac{y a b}{\text { yaa } \times \text { zab }}-\frac{y b a}{y b b x z b a}, A_{g b a}=\frac{y b a}{y b b \times z b a}-\frac{y a b}{\text { yaaxzab }}$

where: $z a b=$ the sown proportion of intercrop a (sugar cane) in combination with b (soybean) and $\mathrm{zba}=$ the sown proportion of intercrop $\mathrm{b}$ (soybean) in combination with (sugar cane).

Actual yield loss (AYL): It was calculated according to Banik (1996) by the following formula: $\mathrm{AYL}=\mathrm{AYLa}+\mathrm{AYLb}$ 
$\mathrm{AYL}=\left\{\frac{y a b / z a b}{y a a / z a a}-1\right\}+\left\{\frac{y b a / z b a}{y b b / z b b}-1\right\}$

where: AYLa and AYLb represent the partial yield loss of a (sugar cane) and b (soybean) intercrops, respectively.

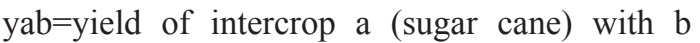
(soybean), yba=yield of intercrop b soybean with a (sugar cane).

Area Time Equivalent Ratio (ATER): it provides more realistic comparison of the yield of intercropping over mono-cropping in terms of time taken by component crops in the intercropping systems according to Hiebsch (1978). ATER was calculated by formula:

$$
\mathrm{ATER}=\left(\mathrm{LER}_{\text {sugar cane }} \mathrm{x} \mathrm{Dc}+\mathrm{LER}_{\text {soybean }} \mathrm{x} \mathrm{Dc}\right) / \mathrm{Dt} .
$$

where, LER is land equivalent ratio of crop, Dc is duration (days) taken by crop. Dt is days taken by whole intercropping system from planting to harvest.

Farmer's benefit: It was calculated by determining the total costs and net return of intercropping culture as compared to recommended solid planting of sugar as follows:

\section{1-Total return :}

-Total return of intercropping cultures $=$ Price sugar cane $\times$ yield + Price soybean $\times$ yield (L.E).

-Total return of sugar cane $=$ Price sugar cane $\times$ yield (L.E).

-Total return of soybean $=$ Price soybean $\times$ yield (L.E).

To calculate the total return, the average of sugar cane 360 L.E ton fad $^{-1}$, soybean 4210 L.E ton $^{-1}$ prices presented by Agriculture Statistics (2014, 2015 and 2016) seasons were used.

- Net return per fad $=$ Total return - (fixed costs of sugar cane + variable costs of soybean according to intercropping pattern).

2- Monetary advantage index (MAI): Suggests that the economic assessment should assessed on the basis of the rentable value of this land. MAI was calculated according to the formula suggested by Willey (1979).

MAI $=\frac{\text { Value of combined intercrops (L.E) } \times(L E R-1)}{L E R}$

\section{Statistical analysis}

The proper statistical analysis of data was done according to Gomez \& Gomez (1984). The differences between means of the studied treatments were compared using least significant difference (LSD) at 5\% level.

\section{$\underline{\text { Result and Discussion }}$}

Soybean

Data in Table 3 indicated that nitrogen fertilizer levels had significant effect on plant height, No. of pods plant ${ }^{-1}, 100$-seed weight, seed yield plant ${ }^{-1}$ and seed yield $\mathrm{kg} \mathrm{fad}^{-1}$ in both seasons and combined analysis as well as No. of branches plant ${ }^{-1}$ in the second season and combined analysis and No. of seeds pod $^{-1}$ in the first season and pod length in combined analysis. Increasing nitrogen level up to $225 \mathrm{kgN} \mathrm{fad}^{-1}$ significantly increased all studied traits in both seasons and combined.

Concerning the values of studied traits in comparison with the values of sole or purestand of soybean, it is clear that the values of sole soybean were higher than soybean plants fertilized by nitrogen levels for most studied characters. Comparing to sole soybean, seed yield fad ${ }^{-1}$ increased by 817.07 , 787.18 and $775.48 \mathrm{~kg} \mathrm{fad}^{-1}$ due to adding 195,210 and $225 \mathrm{kgN} \mathrm{fad}^{-1}$, respectively over the two seasons. These results are probably due to the increase in yield components, i.e. No. of branches plant ${ }^{-1}$, No. of pods plant $^{-1}$, No. of seeds pod ${ }^{-1}, 100$-seed weight and seed yield plant $^{-1}$, which showed that increase nitrogen level resulted better growth of soybean plants.

Table 4 showed that yield and yield components of soybean were significantly affected by its companion with sugar cane, the effect was significant on all studied traits in both seasons and combined analysis, except pod length in both seasons and combined and No. of seeds pod ${ }^{-1}$ in the second season. The highest values of yield and yield components were produced from pure stand for most studied characters. The heaviest seed yield $\mathrm{fad}^{-1}$ attained from pure stand $\left(1227,1166\right.$ and $\left.1197 \mathrm{~kg} \mathrm{fad}^{-1}\right)$ in first, second seasons and combined analysis, respectively compared with either one of intercropping patterns.

On the other hand intercropping pattern of 100\% sugar canes $+40 \%$ soybean, one row gave the highest seed yield compared to the other intercropping patterns. The interpretation for reduction in yield and its components of soybean as compared with grown in pure stand is mainly attributed to the effect of shading sugar cane and its competition for growing needs, which in turn had determined effect of plants in intercropped crop. These results are in good agreement with El-Gergawy et al. (1995), AbouKresha et al. (1997) and Luo et al. (2016). 
TABLE 3. Effect of nitrogen levels on yield and yield components of soybean in 2014/2015, 2015/2016 seasons and combined analysis.

\begin{tabular}{|c|c|c|c|c|c|c|c|c|}
\hline $\begin{array}{l}\text { Nitrogen } \\
\text { levels }\end{array}$ & $\begin{array}{l}\text { Plant } \\
\text { height } \\
\text { (cm.) }\end{array}$ & $\begin{array}{l}\text { No. of } \\
\text { branches }_{\text {plant }^{-1}}\end{array}$ & $\begin{array}{l}\text { No. of } \\
\text { pods } \\
\text { plant }^{-1}\end{array}$ & $\begin{array}{c}\text { pod } \\
\text { Length } \\
(\mathrm{cm})\end{array}$ & $\begin{array}{l}\text { No. of } \\
\text { seeds } \\
\text { pod }^{-1}\end{array}$ & $\begin{array}{c}100- \\
\text { seed } \\
\text { weight } \\
\text { (gm) }\end{array}$ & $\begin{array}{c}\text { Seed } \\
\text { yield } \\
\text { plant } \\
(\mathrm{gm})\end{array}$ & $\underset{\left(\mathrm{kg} \mathrm{fad}^{-1}\right)}{\text { Seed yield }}$ \\
\hline \multicolumn{9}{|c|}{$2014 / 2015$ season } \\
\hline $195 \mathrm{~kg} \mathrm{~N} \mathrm{fad}^{-1}$ & 85.08 & 2.53 & 34.25 & 4.65 & 2.39 & 15.81 & 7.35 & 403.84 \\
\hline $210 \mathrm{~kg} \mathrm{~N}$ fad $^{-1}$ & 97.00 & 2.59 & 44.67 & 4.77 & 2.54 & 16.29 & 7.97 & 433.73 \\
\hline $225 \mathrm{~kg} \mathrm{~N}$ fad $^{-1}$ & 99.13 & 2.65 & 42.25 & 4.79 & 2.67 & 17.73 & 9.54 & 430.37 \\
\hline L.S.D at $5 \%$ & 3.58 & N.S & 7.73 & N.S & 0.17 & 0.39 & 0.17 & 17.30 \\
\hline Sole soybean & 101 & 3.10 & 99.80 & 4.80 & 2.60 & 17.50 & 10.62 & 1227 \\
\hline \multicolumn{9}{|c|}{ 2015/2016 season } \\
\hline $195 \mathrm{~kg} \mathrm{~N} \mathrm{fad}^{-1}$ & 99.83 & 1.92 & 23.73 & 4.02 & 2.55 & 14.27 & 5.70 & 356.03 \\
\hline $210 \mathrm{~kg} \mathrm{~N} \mathrm{fad}^{-1}$ & 111.42 & 2.41 & 28.42 & 4.15 & 2.63 & 15.15 & 6.81 & 385.90 \\
\hline $225 \mathrm{~kg} \mathrm{~N} \mathrm{fad}^{-1}$ & 114.25 & 2.53 & 35.17 & 4.46 & 2.85 & 15.96 & 8.82 & 412.68 \\
\hline L.S.D at $5 \%$ & 3.69 & 0.23 & 2.03 & N.S & N.S & 0.08 & 0.18 & 6.02 \\
\hline Sole soybean & 98.67 & 2.54 & 89.30 & 4.50 & 2.13 & 12.27 & 8.00 & 1166 \\
\hline \multicolumn{9}{|c|}{ Combined } \\
\hline $195 \mathrm{~kg} \mathrm{~N} \mathrm{fad}^{-1}$ & 92.46 & 2.23 & 28.99 & 4.33 & 2.47 & 15.04 & 6.53 & 379.93 \\
\hline $210 \mathrm{~kg} \mathrm{~N} \mathrm{fad}^{-1}$ & 104.21 & 2.50 & 36.54 & 4.46 & 2.58 & 15.72 & 7.39 & 409.82 \\
\hline $225 \mathrm{~kg} \mathrm{~N} \mathrm{fad}^{-1}$ & 106.69 & 2.59 & 38.71 & 4.62 & 2.56 & 16.84 & 9.18 & 421.52 \\
\hline L.S.D at $5 \%$ & 2.13 & 0.11 & 3.32 & 0.19 & N.S & 0.36 & 0.10 & 7.60 \\
\hline Sole soybean & 99.84 & 2.82 & 94.55 & 4.65 & 2.63 & 17.17 & 9.31 & 1197 \\
\hline
\end{tabular}

The interaction effect was significant on plant height, No. of branches, and 100 -seed weight in the second season and over the two seasons (combined), as well as seed yield plant $^{-1}$ and seed yield $\mathrm{fad}^{-1}$ in both seasons and combined analysis and No. of pods plant ${ }^{-1}$ in the second season (Table 5).

Generally it is clear that increasing nitrogen level up to $225 \mathrm{~kg} \mathrm{fad}^{-1}$ with intercropping pattern of $100 \%$ sugar cane $+40 \%$ soybean in one row or two rows gave the highest values of seed weight plant ${ }^{-1}$ and per fad.

\section{Sugar cane}

Data in Table 6 indicated that increasing $\mathrm{N}$ - level up to $225 \mathrm{kgN} \mathrm{fad}^{-1}$ caused significant differences on stalk high, stalk diameter and cane yield fad ${ }^{-1}$ in both seasons and over the two seasons (combined), as well as the effect was insignificant on stalk weight over the two seasons(combined). On the other hand the effect was insignificant on No. of internodes stalk $\mathrm{k}^{-1}$ in both seasons and combined analysis, as well as, stalk weight in both seasons.
Increasing $\mathrm{N}-$ level up to $225 \mathrm{kgN}$ fad ${ }^{1}$ recorded the highest values of stalk height, stalk weight and cane yield. Such results have been expected and maybe attributed to the role of nitrogen in building up the photosynthetic area of sugar cane plants and consequently gave the highest values of yield and its components. Similar results obtained by Ramouthar et al. (2013).

Concerning the effect of $\mathrm{N}$ fertilizer levels on sugar yield of sugar cane (Table 6), it is clear that no significant effect on second season, as well as significant effect on first season and over the two seasons (combined). The data in Table 6 showed clearly the significant responses of sugar yield (ton $\mathrm{fad}^{-1}$ ) to the different nitrogen levels added and that more higher sugar yield was gained associated with higher nitrogen levels up to $225 \mathrm{~kg} \mathrm{fad}^{-1}$. These results ensure the vital importance of nitrogen fertilization with sufficient level to obtain economical high sugar yield. 
TABLE 4. Effect of intercropping patterns of soybean on yield and yield components of soybean in 2014/2015, 2015/2016 and combined analysis.

\begin{tabular}{|c|c|c|c|c|c|c|c|c|}
\hline Intercropping patterns & $\begin{array}{l}\text { Plant } \\
\text { height } \\
(\mathrm{cm})\end{array}$ & $\begin{array}{c}\text { No. of } \\
\text { branches } \\
\text { plant }^{-1}\end{array}$ & $\begin{array}{l}\text { No. of } \\
\text { pods } \\
\text { plant }^{-1}\end{array}$ & $\begin{array}{l}\text { Pod } \\
\text { length } \\
(\mathrm{cm})\end{array}$ & $\begin{array}{c}\text { No, of } \\
\text { seeds } \\
\text { pod }^{-1}\end{array}$ & $\begin{array}{c}100- \\
\text { seed } \\
\text { weight } \\
(\mathrm{gm})\end{array}$ & $\begin{array}{c}\text { Seed } \\
\text { yield } \\
\text { plant }^{-1} \\
(\mathrm{gm})\end{array}$ & $\begin{array}{c}\text { Seed } \\
\text { yield (kg } \\
\left.\text { fad }^{-1}\right)\end{array}$ \\
\hline \multicolumn{9}{|c|}{$2014 / 2015$ season } \\
\hline $\begin{array}{l}100 \% \text { sugar cane }+30 \% \text { soybean } \\
\text { one row }\end{array}$ & 96.56 & 2.62 & 52.78 & 4.84 & 2.56 & 17.48 & 8.61 & 384.21 \\
\hline $\begin{array}{l}100 \% \text { sugar cane }+30 \% \text { soybean } \\
\text { two rows }\end{array}$ & 93.44 & 2.47 & 31.22 & 4.65 & 2.30 & 16.58 & 7.29 & 409.23 \\
\hline $\begin{array}{l}100 \% \text { sugar cane }+40 \% \text { soybean } \\
\text { one row }\end{array}$ & 94.67 & 2.77 & 44.00 & 4.74 & 2.76 & 17.12 & 9.48 & 483.10 \\
\hline $\begin{array}{l}100 \% \text { sugar cane }+40 \% \text { soybean } \\
\text { two rows }\end{array}$ & 90.28 & 2.51 & 33.56 & 4.71 & 2.52 & 15.25 & 7.76 & 414.04 \\
\hline L.S.D at $5 \%$ & 3.38 & 0.14 & 9.25 & N.S & 0.13 & 0.82 & 0.28 & 15.33 \\
\hline Sole soybean & 101 & 3.10 & 99.80 & 4.80 & 2.60 & 17.50 & 10.62 & 1227 \\
\hline \multicolumn{9}{|c|}{ 2015/2016 season } \\
\hline $\begin{array}{l}100 \% \text { sugar cane }+30 \% \text { soybean } \\
\text { one row }\end{array}$ & 112.33 & 2.18 & 30.32 & 4.29 & 2.76 & 16.14 & 8.40 & 349.01 \\
\hline $\begin{array}{l}100 \% \text { sugar cane }+30 \% \text { soybean } \\
\text { two rows }\end{array}$ & 108.00 & 2.35 & 24.68 & 4.19 & 2.55 & 14.36 & 6.22 & 321.07 \\
\hline $\begin{array}{l}100 \% \text { sugar cane }+40 \% \text { soybean } \\
\text { one row }\end{array}$ & 107.67 & 2.52 & 32.91 & 4.19 & 2.80 & 15.47 & 7.64 & 454.54 \\
\hline $\begin{array}{l}100 \% \text { sugar cane }+40 \% \text { soybean } \\
\text { two rows }\end{array}$ & 106.00 & 2.09 & 28.50 & 4.17 & 2.59 & 14.54 & 6.17 & 414.87 \\
\hline L.S.D at $5 \%$ & 3.33 & 0.25 & 1.21 & N.S & N.S & 0.61 & 0.34 & 8.07 \\
\hline Sole soybean & 98.67 & 2.54 & 89.30 & 4.50 & 2.13 & 12.27 & 8.00 & 1166 \\
\hline \multicolumn{9}{|c|}{ Combined } \\
\hline $\begin{array}{l}100 \% \text { sugar cane }+30 \% \text { soybean } \\
\text { one row }\end{array}$ & 104.44 & 2.40 & 41.55 & 4.57 & 2.66 & 16.81 & 8.51 & 366.61 \\
\hline $\begin{array}{l}100 \% \text { sugar cane }+30 \% \text { soybean two } \\
\text { rows }\end{array}$ & 100.72 & 2.41 & 27.95 & 4.42 & 2.43 & 15.47 & 6.76 & 365.15 \\
\hline $\begin{array}{l}100 \% \text { sugar cane }+40 \% \text { soybean } \\
\text { one row }\end{array}$ & 101.17 & 2.65 & 38.46 & 4.46 & 2.78 & 16.30 & 8.56 & 468.82 \\
\hline $\begin{array}{l}100 \% \text { sugar cane }+40 \% \text { soybean } \\
\text { two rows }\end{array}$ & 98.14 & 2.30 & 31.03 & 4.44 & 2.57 & 14.90 & 6.96 & 414.46 \\
\hline L.S.D at $5 \%$ & 2.29 & 0.14 & 4.51 & N.S & 0.12 & 0.50 & 0.21 & 8.37 \\
\hline Sole soybean & 99.84 & 2.82 & 94.55 & 4.65 & 2.63 & 17.17 & 9.31 & 1197 \\
\hline
\end{tabular}

The results in Table 7 showed that intercropping patterns of soybean on sugar cane had a significant effect on stalk height, stalk weight and can yield $\mathrm{fad}^{-1}$ in both seasons and over the two seasons and stalk diameter in the $2^{\text {nd }}$ season. Otherwise, insignificant effect was recorded on No. of internodes stalk ${ }^{-1}$ in both seasons and over the two seasons and sugar yield in the $1^{\text {st }}$ season.

It could be observed that intercropping pattern of $100 \%$ sugar cane $+40 \%$ soybean in one row gave the highest values of stalk high and cane yield fad $^{-1}$.

It is worth mentioning that the increase in stalk height compared with pure stand of sugar cane may be due to the competition between soybean and sugar cane plants and fixed nitrogen by soybean in the case of intercropping which in turn increased stalk height (Teshome et al., 2015). 
TABLE 5. Effect of interaction between nitrogen levels and intercropping patterns of soybean on some traits of soybean in 2014/2015, 2015/2016 and combined analysis.

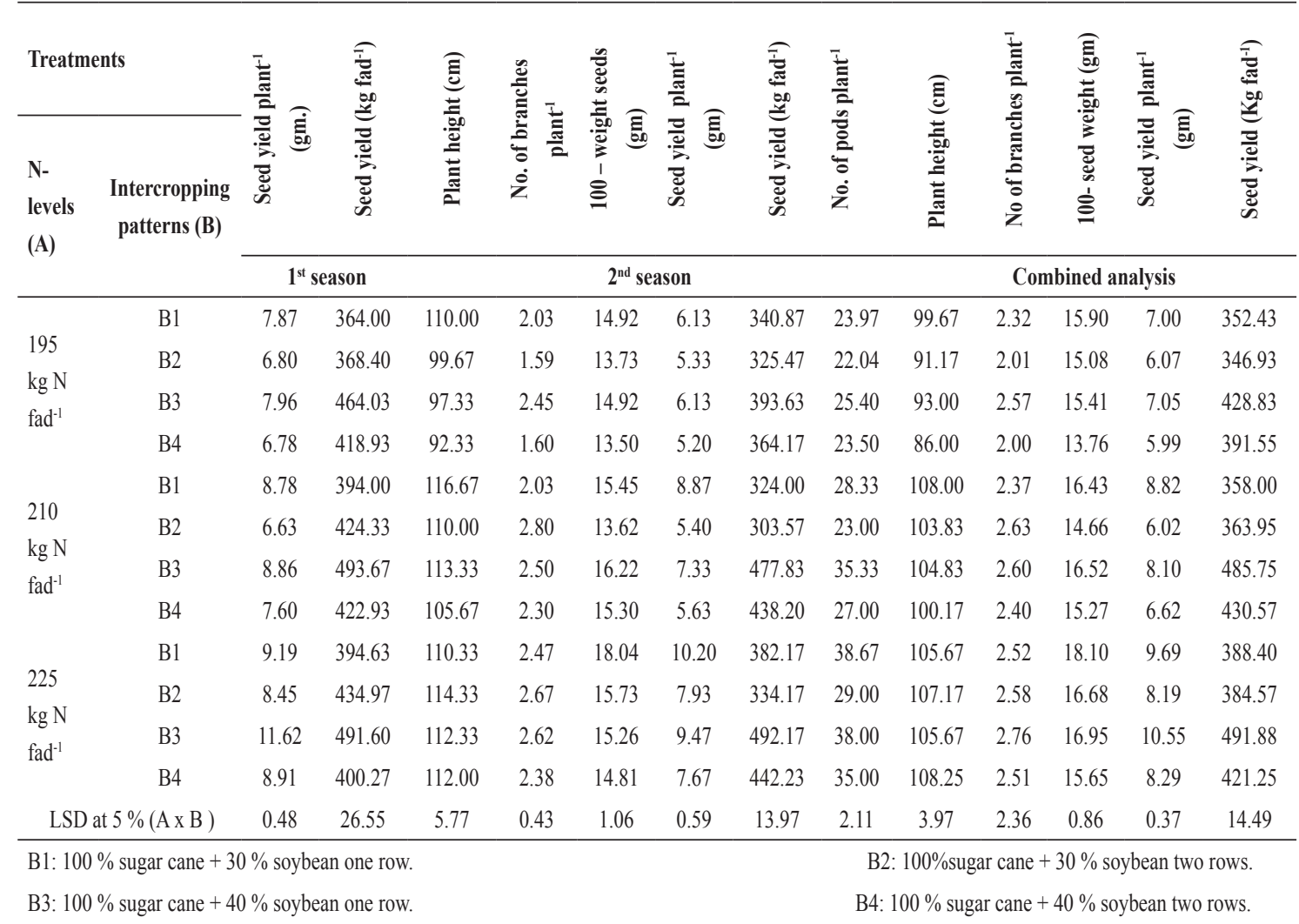

TABLE 6. Effect of nitrogen levels on yield and yield components of sugarcane in 2014/2015, 2015/2016 seasons and combined analysis.

\begin{tabular}{|c|c|c|c|c|c|c|}
\hline Nitrogen levels & $\begin{array}{c}\text { Stalk } \\
\text { height } \\
(\mathrm{cm})\end{array}$ & $\begin{array}{c}\text { Stalk } \\
\text { diameter } \\
(\mathrm{cm})\end{array}$ & $\begin{array}{c}\text { No. of } \\
\text { internodes } \\
\text { stalk }^{-1}\end{array}$ & $\begin{array}{c}\text { Stalk } \\
\text { weight (kg) }\end{array}$ & $\begin{array}{l}\text { Cane yield } \\
\left(\text { ton } \text { fad }^{-1}\right)\end{array}$ & $\begin{array}{l}\text { Sugar yield } \\
\left(\text { ton } \text { fad }^{-1}\right)\end{array}$ \\
\hline \multicolumn{7}{|c|}{$2014 / 2015$ season } \\
\hline $195 \mathrm{~kg} \mathrm{~N} \mathrm{fad}^{-1}$ & 195.42 & 2.54 & 16.35 & 1.15 & 44.28 & 5.41 \\
\hline $210 \mathrm{~kg} \mathrm{~N} \mathrm{fad}^{-1}$ & 204.17 & 2.51 & 15.61 & 1.20 & 46.81 & 5.89 \\
\hline $225 \mathrm{~kg} \mathrm{~N} \mathrm{fad}^{-1}$ & 214.75 & 2.36 & 16.33 & 1.28 & 48.83 & 6.04 \\
\hline L.S.D at $5 \%$ & 5.33 & 0.11 & N.S & N.S & 0.89 & 0.33 \\
\hline Sole sugar cane & 180.7 & 2.33 & 14.9 & 1.06 & 45.99 & 5.69 \\
\hline \multicolumn{7}{|c|}{$2015 / 2016$ season } \\
\hline $195 \mathrm{~kg} \mathrm{~N} \mathrm{fad}^{-1}$ & 190.42 & 2.49 & 16.17 & 1.20 & 45.22 & 5.63 \\
\hline $210 \mathrm{~kg} \mathrm{~N} \mathrm{fad}^{-1}$ & 199.33 & 2.50 & 15.93 & 1.23 & 48.43 & 6.08 \\
\hline $225 \mathrm{~kg} \mathrm{~N} \mathrm{fad}^{-1}$ & 218.50 & 2.34 & 16.31 & 1.30 & 51.33 & 6.41 \\
\hline L.S.D at $5 \%$ & 4.03 & 0.07 & N.S & N.S & 1.60 & N.S \\
\hline Sole sugar cane & 190.7 & 2.57 & 16.03 & 1.16 & 47.13 & 6.69 \\
\hline \multicolumn{7}{|c|}{ Combined } \\
\hline $195 \mathrm{~kg} \mathrm{~N} \mathrm{fad}^{-1}$ & 192.92 & 2.52 & 16.26 & 1.18 & 44.75 & 5.52 \\
\hline $210 \mathrm{~kg} \mathrm{~N} \mathrm{fad}^{-1}$ & 201.75 & 2.50 & 15.77 & 1.21 & 47.62 & 5.99 \\
\hline $225 \mathrm{~kg} \mathrm{~N} \mathrm{fad}^{-1}$ & 216.63 & 2.35 & 16.32 & 1.29 & 50.08 & 6.23 \\
\hline L.S.D at $5 \%$ & 3.43 & 0.06 & N.S & 0.07 & 0.67 & 0.25 \\
\hline Sole sugar cane & 185.7 & 2.45 & 15.46 & 1.11 & 46.56 & 6.19 \\
\hline
\end{tabular}


TABLE 7. Effect of intercropping patterns of soybean with sugarcane on yield and yield component of sugarcane in 2014/2015, 2015/2016 and combined analysis.

\begin{tabular}{|c|c|c|c|c|c|c|}
\hline Intercropping patterns & $\begin{array}{c}\text { Stalk } \\
\text { height } \\
(\mathrm{cm})\end{array}$ & $\begin{array}{c}\text { Stalk } \\
\text { diameter } \\
(\mathrm{cm})\end{array}$ & $\begin{array}{l}\text { No. of internodes } \\
\text { stalk }^{-1}\end{array}$ & $\begin{array}{l}\text { Stalk weight } \\
(\mathrm{kg})\end{array}$ & $\begin{array}{l}\text { Cane yield } \\
\text { (ton fad }^{-1} \text { ) }\end{array}$ & $\begin{array}{c}\text { Sugar yield } \\
\left(\text { ton fad } \text { fad }^{-1}\right)\end{array}$ \\
\hline \multicolumn{7}{|c|}{ 2014/2015 Season } \\
\hline $100 \%$ sugar cane $+30 \%$ soybean one row & 199.22 & 2.49 & 16.00 & 1.15 & 45.66 & 5.72 \\
\hline $100 \%$ sugar cane $+30 \%$ soybean two rows & 200.00 & 2.50 & 15.98 & 1.17 & 43.73 & 5.35 \\
\hline $100 \%$ sugar cane $+40 \%$ soybean one row & 211.22 & 2.43 & 16.28 & 1.29 & 49.42 & 6.17 \\
\hline $100 \%$ sugar cane $+40 \%$ soybean two rows & 208.67 & 2.46 & 16.13 & 1.24 & 47.76 & 5.88 \\
\hline L.S.D at $5 \%$ & 6.52 & N.S & N.S & 0.07 & 1.45 & N.S \\
\hline Sole sugar cane & 180.7 & 2.33 & 14.9 & 1.06 & 45.99 & 5.69 \\
\hline \multicolumn{7}{|c|}{ 2015/2016 Season } \\
\hline $100 \%$ sugar cane $+30 \%$ soybean one row & 202.22 & 2.44 & 16.11 & 1.20 & 47.14 & 6.00 \\
\hline $100 \%$ sugar cane $+30 \%$ soybean two rows & 198.67 & 2.34 & 15.82 & 1.24 & 45.78 & 5.53 \\
\hline $100 \%$ sugar cane $+40 \%$ soybean one row & 206.44 & 2.51 & 16.48 & 1.25 & 50.89 & 6.48 \\
\hline $100 \%$ sugar cane $+40 \%$ soybean two rows & 203.67 & 2.48 & 16.13 & 1.27 & 49.49 & 6.16 \\
\hline L.S.D at $5 \%$ & 5.31 & 0.09 & N.S & 0.03 & 1.33 & 0.35 \\
\hline Sole sugar cane & 190.7 & 2.57 & 16.03 & 1.16 & 47.13 & 6.69 \\
\hline \multicolumn{7}{|c|}{ Combined } \\
\hline $100 \%$ sugar cane $+30 \%$ soybean one row & 200.72 & 2.47 & 16.06 & 1.17 & 46.40 & 5.86 \\
\hline $100 \%$ sugar cane $+30 \%$ soybean two rows & 199.33 & 2.42 & 15.90 & 1.20 & 44.76 & 5.44 \\
\hline $100 \%$ sugar cane $+40 \%$ soybean one row & 208.83 & 2.47 & 16.38 & 1.27 & 50.16 & 6.33 \\
\hline $100 \%$ sugar cane $+40 \%$ soybean two rows & 206.17 & 2.47 & 16.13 & 1.26 & 48.62 & 6.02 \\
\hline L.S.D at $5 \%$ & 4.06 & N.S & N.S & 0.04 & 0.95 & 0.31 \\
\hline Sole sugar cane & 185.7 & 2.45 & 15.46 & 1.11 & 46.56 & 6.19 \\
\hline
\end{tabular}

The highest values of stalk weight and cane yield were obtained when applying intercropping pattern of $100 \%$ sugar cane $+40 \%$ soybean in one row, than those of intercropping pattern of $100 \%$ sugar cane $+30 \%$ soybean.

In general, resulting the great cane yield $\mathrm{fad}^{-1}$ from intercropping pattern of $100 \%$ sugar cane with $40 \%$ soybean compared with pure stand of soybean. This result may be due to soybean in intercropping increase productivity per unit area of land and enables the crop more effectively utilize nutrients and improve soil fertility and field ecological conditions. Similar results recorded by Tang et al. (2005) and Khandgave (2010).

The interaction between $\mathrm{N}$ levels and intercropping patterns (Table 8) was significant with respect to stalk weight and cane yield $\mathrm{fad}^{-1}$ in the second season and over the two seasons (combined). The highest value of stalk weight obtained from $100 \%$ sugar cane $+40 \%$ soybean in two rows with $225 \mathrm{kgN} \mathrm{fad}^{-1}$. Also, the greatest cane yield $\mathrm{fad}^{-1}$ produced from $100 \%$ sugar cane +40 soybean, one row with $225 \mathrm{kgN} \mathrm{fad}^{-1}$ in the second season and over the two seasons(combined). These finding may be attributed to the role of nitrogen fertilizer in sugar cane growth and intercropping with $40 \%$ soybean improved the soil inorganic nitrogen compared with sole plantation of sugar cane. Xiuping et al. (2013) obtained similar results.

Concerning the effect of nitrogen fertilizer levels on quality parameters (Table 9), it is clear that no significant effect on all quality parameters in both seasons except purity $\%$ in second season and TSS \% and purity \%in over the two seasons (combined analysis) which has significant effect.

Data in Tables 7 and10 showed the effect of intercropping soybean on juice quality and yield of sugar yield fad ${ }^{-1}$ and could be cleared 
TABLE 8. Effect of interaction between nitrogen levels and intercropping patterns of soybean on stalk weight and cane yield fad $^{-1}$ in the second season and combined analysis.

\begin{tabular}{|c|c|c|c|c|c|}
\hline & \multirow[t]{2}{*}{ Treatment } & $\begin{array}{c}\text { Stalk } \\
\text { weight } \\
\text { (kg) }\end{array}$ & $\begin{array}{l}\text { Cane yield } \\
\left(\text { ton } \text { fad }^{-1}\right)\end{array}$ & $\begin{array}{c}\text { Stalk weight } \\
\text { (kg) }\end{array}$ & $\begin{array}{r}\text { Cane yield } \\
\left(\text { ton } \text { fad }^{-1}\right)\end{array}$ \\
\hline & & \multicolumn{2}{|c|}{$2^{\text {nd }}$ season } & \multicolumn{2}{|c|}{ Combined } \\
\hline \multirow{5}{*}{$\begin{array}{l}195 \\
\operatorname{kg~N} \text { fad }^{-1}\end{array}$} & $30 \%$ soybean one row & 1.12 & 44.68 & 1.07 & 44.77 \\
\hline & $30 \%$ soybean two rows & 1.19 & 43.68 & 1.16 & 43.03 \\
\hline & $40 \%$ soybean one row & 1.24 & 46.68 & 1.25 & 46.27 \\
\hline & $40 \%$ soybean two rows & 1.24 & 45.87 & 1.22 & 45.23 \\
\hline & $30 \%$ soybean one row & 1.23 & 46.83 & 1.19 & 46.10 \\
\hline \multirow{2}{*}{$\begin{array}{l}210 \\
\mathrm{~kg} \mathrm{~N} \mathrm{fad}^{-1}\end{array}$} & $30 \%$ soybean two rows & 1.20 & 44.10 & 1.16 & 43.78 \\
\hline & $40 \%$ soybean one row & 1.25 & 52.23 & 1.27 & 51.32 \\
\hline \multirow{5}{*}{$\begin{array}{l}225 \\
\mathrm{~kg} \mathrm{~N} \mathrm{fad}^{-1}\end{array}$} & $40 \%$ soybean two rows & 1.23 & 50.53 & 1.23 & 49.27 \\
\hline & $30 \%$ soybean one row & 1.25 & 49.93 & 1.25 & 48.63 \\
\hline & $30 \%$ soybean two rows & 1.32 & 49.57 & 1.30 & 47.45 \\
\hline & $40 \%$ soybean one row & 1.26 & 53.77 & 1.28 & 52.88 \\
\hline & $40 \%$ soybean two rows & 1.35 & 52.97 & 1.33 & 51.37 \\
\hline \multicolumn{2}{|r|}{ L.S.D.at $5 \%(\mathrm{~A} \times \mathrm{B})$} & 0.06 & 2.31 & 0.06 & 1.65 \\
\hline
\end{tabular}

that differences between intercropping patterns were not enough to attain significant effect on juice quality, while the effect was significant on sugar yield $\mathrm{fad}^{-1}$ in the second season and over the two seasons (combined).

In general, pure stand of sugar cane gave the highest values of sugar yield fad 1 and juice quality parameters. This finding indicate that under the high canopy conditions (intercropping), sugar cane plants failed to attain the highest profit from the available ecosystem such as light, nutrients, water, etc.. compared with plants grown in pure stand, which partially profited from the environments. These results are in agreement with EL-Gergawy et al. (1995) and Teshome et al. (2015).

\section{Competitive relationships and yield advantage}

Results of competitive relationships and yield advantage for intercropping soybean with sugar cane under nitrogen levels and four patterns combined are presented in Table 11. Data showed that intercropping soybean with sugar cane resulted in an advantage in land equivalent ratio (LER).

The value of LER is greater than one, which indicatedthat increasing the land productivity per unit area. The highest value of LER (1.56) obtained by intercropping 100\% sugar cane $+40 \%$ soybean in one row with $225 \mathrm{kgN}$ fad $^{-}$ 1 , while the lowest one (1.21) recorded from intercropping $100 \%$ sugar cane $+30 \%$ soybean in two rows with $195 \mathrm{kgN} \mathrm{fad}^{-1}$. Also, ATER values cleared that the highest value obtained from $100 \%$ sugar cane with $40 \%$ soybean in one row, while the lowest one recorded from $100 \%$ sugar cane with $30 \%$ soybean in two rows with $195 \mathrm{~kg} \mathrm{~N} \mathrm{fad}^{-1}$.Aggressivity (Agg) values of sugar cane were positive (dominant), while those of soybean were negative (dominated)by intercropping $100 \%$ sugar cane $+40 \%$ soybean in two rows. The best value of aggressivity was recorded from intercropping 100\% sugar cane with $30 \%$ soybean in one row with $210 \mathrm{kgN} \mathrm{fad}^{-1}$, while the lowest value obtained by intercropping $40 \%$ soybean in two rows with $225 \mathrm{kgN} \mathrm{fad}^{-1}$.

Belong to actual yield loss (AYL) values for sugar cane and soybean were positive at all intercropping patterns. The highest value (1.02) of total AYL was obtained from intercropping $40 \%$ soybean in one row with $225 \mathrm{kgN}$ fad $^{-}$ ${ }^{1}$., while the lowest one (0.46) was recorded from intercropping $30 \%$ soybean in two rows. These results means that the intercropping soybean on sugar cane increased values of yield, yield components and quality parameters in intercropping patterns than sowing the same crop in pure stand. The results of Tahir et al. (2003), Khan \& Khaliq (2004), Dhima et al.(2007), Teshome et al. (2015), Khippal (2016)and Luo et al. (2016) supported the current finding.

Egypt.J.Agron. Vol.39, No.2 (2017) 
TABLE9. Effect of nitrogen levels on quality parameters of sugarcane in 2014/2015, 2015/2016 and combined analysis.

\begin{tabular}{|c|c|c|c|c|c|c|}
\hline Nitrogen levels & TSS $\%$ & Sucrose \% & Purity \% & Pol \% & $\begin{array}{l}\text { Reducing } \\
\text { sugar \% }\end{array}$ & $\begin{array}{c}\text { Sugar } \\
\text { recovery } \%\end{array}$ \\
\hline \multicolumn{7}{|c|}{ 2014/2015 season } \\
\hline $195 \mathrm{Kg} \mathrm{N} \mathrm{dad}^{-1}$ & 20.71 & 17.71 & 83.61 & 14.45 & 0.40 & 12.09 \\
\hline $210 \mathrm{Kg} \mathrm{N} \mathrm{fad}^{-1}$ & 20.96 & 18.35 & 84.29 & 14.90 & 0.39 & 12.38 \\
\hline $225 \mathrm{Kg} \mathrm{N} \mathrm{fad}^{-1}$ & 21.42 & 17.92 & 83.69 & 14.60 & 0.40 & 12.07 \\
\hline L.S.D at $5 \%$ & N.S & N.S & N.S & N.S & N.S & N.S \\
\hline Sole sugar cane & 21.30 & 18.17 & 84.97 & 14.65 & 0.37 & 12.22 \\
\hline \multicolumn{7}{|c|}{$2015 / 2016$ season } \\
\hline $195 \mathrm{Kg} \mathrm{N} \mathrm{dad}^{-1}$ & 21.24 & 18.22 & 83.67 & 14.51 & 0.41 & 12.45 \\
\hline $210 \mathrm{Kg} \mathrm{N} \mathrm{fad}^{-1}$ & 21.43 & 18.90 & 84.58 & 15.00 & 0.41 & 12.57 \\
\hline $225 \mathrm{Kg} \mathrm{N} \mathrm{fad}^{-1}$ & 21.80 & 18.48 & 83.87 & 14.65 & 0.41 & 12.47 \\
\hline L.S.D at $5 \%$ & N.S & N.S & 0.43 & N.S & N.S & N.S \\
\hline Sole sugar cane & 22.40 & 19.32 & 84.50 & 15.32 & 0.40 & 13.10 \\
\hline \multicolumn{7}{|c|}{ Combined } \\
\hline $195 \mathrm{Kg} \mathrm{N} \mathrm{fad}^{-1}$ & 20.98 & 17.97 & 83.70 & 14.48 & 0.41 & 12.27 \\
\hline $210 \mathrm{Kg} \mathrm{N} \mathrm{fad}^{-1}$ & 21.19 & 18.63 & 84.43 & 14.95 & 0.40 & 12.48 \\
\hline $225 \mathrm{Kg} \mathrm{N} \mathrm{fad}^{-1}$ & 21.61 & 18.20 & 83.78 & 14.63 & 0.41 & 12.27 \\
\hline L.S.D at $5 \%$ & 0.26 & N.S & 0.27 & N.S & N.S & N.S \\
\hline Sole sugar cane & 21.85 & 18.75 & 84.74 & 14.64 & 0.39 & 12.25 \\
\hline
\end{tabular}

TABLE 10. Effect intercropping patterns of soybean on quality parameters of sugar cane in 2014/2015, 2015/2016 and combined analysis.

\begin{tabular}{|c|c|c|c|c|c|c|}
\hline Intercropping patterns & TSS $\%$ & $\begin{array}{c}\text { Sucrose } \\
\%\end{array}$ & $\begin{array}{c}\text { Purity } \\
\%\end{array}$ & $\begin{array}{l}\text { Pol } \\
\%\end{array}$ & $\begin{array}{c}\text { Reducing } \\
\text { sugars } \\
\%\end{array}$ & $\begin{array}{c}\text { Sugar } \\
\text { recovery\% }\end{array}$ \\
\hline \multicolumn{7}{|c|}{$2014 / 2015$ season } \\
\hline $100 \%$ sugar cane $+30 \%$ soybean one row & 21.06 & 18.32 & 84.26 & 14.87 & 0.39 & 12.40 \\
\hline $100 \%$ sugar cane $+30 \%$ soybean two rows & 20.94 & 17.71 & 83.83 & 14.43 & 0.39 & 11.95 \\
\hline $100 \%$ sugar cane $+40 \%$ soybean one row & 21.39 & 18.16 & 83.89 & 14.78 & 0.40 & 12.32 \\
\hline $100 \%$ sugar cane $+40 \%$ soybean two rows & 20.72 & 17.79 & 83.48 & 14.52 & 0.40 & 12.09 \\
\hline L.S.D at $5 \%$ & N.S & N.S & N.S & N.S & N.S & N.S \\
\hline Sole sugar cane & 21.30 & 18.17 & 84.97 & 14.65 & 0.37 & 12.22 \\
\hline \multicolumn{7}{|c|}{ 2015/2016 season } \\
\hline $100 \%$ sugar cane $+30 \%$ soybean one row & 21.73 & 18.87 & 84.51 & 15.09 & 0.40 & 12.74 \\
\hline $100 \%$ sugar cane $+30 \%$ soybean two rows & 21.32 & 18.47 & 83.94 & 14.69 & 0.41 & 12.09 \\
\hline $100 \%$ sugar cane $+40 \%$ soybean one row & 21.58 & 18.36 & 84.16 & 14.52 & 0.42 & 12.72 \\
\hline $100 \%$ sugar cane $+40 \%$ soybean two rows & 21.32 & 18.44 & 83.69 & 14.57 & 0.41 & 12.43 \\
\hline L.S.D at $5 \%$ & N.S & N.S & N.S & N.S & N.S & N.S \\
\hline Sole sugar cane & 22.40 & 19.32 & 84.50 & 15.32 & 0.40 & 13.10 \\
\hline \multicolumn{7}{|c|}{ Combined } \\
\hline $100 \%$ sugar cane $+30 \%$ soybean one row & 21.39 & 18.60 & 84.38 & 14.98 & 0.39 & 12.55 \\
\hline $100 \%$ sugar cane $+30 \%$ soybean two rows & 21.13 & 18.09 & 83.89 & 14.56 & 0.40 & 12.02 \\
\hline $100 \%$ sugar cane $+40 \%$ soybean one row & 21.48 & 18.26 & 84.02 & 14.65 & 0.41 & 12.52 \\
\hline $100 \%$ sugar cane $+40 \%$ soybean two rows & 21.02 & 18.12 & 83.58 & 14.55 & 0.40 & 12.26 \\
\hline L.S.D at $5 \%$ & N.S & N.S & N.S & N.S & N.S & N.S \\
\hline Sole sugar cane & 21.85 & 18.75 & 84.74 & 16.64 & 0.39 & 12.25 \\
\hline
\end{tabular}


TABLE11. Calculated data of competitive relationships and yield advantage for intercropping patterns of soybean with sugar cane (combined of seasons).

\begin{tabular}{|c|c|c|c|c|c|c|}
\hline \multirow{2}{*}{\multicolumn{2}{|c|}{$\begin{array}{l}\text { Intercropping } \\
\text { patterns }\end{array}$}} & \multirow[b]{2}{*}{$\begin{array}{c}\text { LER }= \\
\text { LER }+ \text { LER } \\
\text { Sugarcane } \quad \text { Soybean }\end{array}$} & \multirow[b]{2}{*}{ ATER } & \multicolumn{2}{|c|}{ Aggressivity (A) } & \multirow[b]{2}{*}{$\begin{array}{c}\text { AYL }= \\
\text { AYLSugarcane + } \\
\text { AYLSoybean }\end{array}$} \\
\hline & & & & $\begin{array}{c}\text { (A) } \\
\text { Sugarcane }\end{array}$ & $\begin{array}{c}\text { (A) } \\
\text { Soybean }\end{array}$ & \\
\hline \multirow{4}{*}{$\begin{array}{l}\left(\mathrm{A}_{1}\right) \\
195 \\
\mathrm{~N} \mathrm{~kg} \mathrm{fad}^{-1}\end{array}$} & B1 & $0.96+0.29=1.25$ & 1.04 & -0.03 & +0.03 & $0.25+0.28=0.53$ \\
\hline & B2 & $0.92+0.29=1.21$ & 1.00 & -0.06 & +0.06 & $0.20+0.26=0.46$ \\
\hline & B3 & $0.99+0.36=1.35$ & 1.09 & +0.16 & -0.16 & $0.40+0.24=0.64$ \\
\hline & B4 & $0.97+0.33=1.30$ & 1.06 & +0.24 & -0.24 & $0.37+0.13=0.50$ \\
\hline \multirow{4}{*}{$\begin{array}{l}\left(\mathrm{A}_{2}\right) \\
210 \\
\mathrm{~N} \mathrm{~kg} \mathrm{fad}^{-1}\end{array}$} & B1 & $0.99+0.30=1.29$ & 1.07 & -0.01 & +0.01 & $0.29+0.30=0.59$ \\
\hline & B2 & $0.94+0.30=1.24$ & 1.02 & -0.10 & +0.10 & $0.22+0.32=0.54$ \\
\hline & B3 & $1.10+0.41=1.51$ & 1.21 & +0.15 & -0.15 & $0.55+0.40=0.95$ \\
\hline & B4 & $1.06+0.36=1.42$ & 1.16 & +0.25 & -0.25 & $0.49+0.24=0.73$ \\
\hline \multirow{4}{*}{$\begin{array}{l}\left(\mathrm{A}_{3}\right) \\
225 \\
\mathrm{~N} \mathrm{~kg} \mathrm{fad}^{-1}\end{array}$} & B1 & $1.05+0.32=1.37$ & 1.14 & -0.05 & +0.05 & $0.36+0.41=0.77$ \\
\hline & B2 & $1.02+0.32=1.34$ & 1.11 & -0.08 & +0.08 & $0.32+0.40=0.72$ \\
\hline & B3 & $1.14+0.42=1.56$ & 1.25 & +0.18 & -0.18 & $0.60+0.42=1.02$ \\
\hline & B4 & $1.10+0.35=1.45$ & 1.19 & +0.34 & -0.34 & $0.55+0.21=0.76$ \\
\hline
\end{tabular}

$\mathrm{B} 1=100 \%$ sugar cane $+30 \%$ soybean one rows.

$\mathrm{B} 3=100 \%$ sugar cane $+40 \%$ soybean one rows

\section{Economic analysis}

It is clear from the results in Table 12 that the intercropping patterns of soybean on sugar cane led to increase total income and its total return or profit L.E fad $^{-1}$ and Monetary advantage index (MAI). Data showed that the highest values of total income and total return (21108 and 10746 L.E fad $\left.{ }^{-1}\right)$, respectively obtained from $100 \%$ sugar cane $+40 \%$ soybean in one row with $225 \mathrm{kgN} \mathrm{fad}^{-1}(\mathrm{~A} 3 \times \mathrm{B} 3)$, the same trend was true in Monetary advantage index (MAI) was 7577.23. Total return of intercropping sugar cane
$\mathrm{B} 2=100 \%$ sugar cane $+30 \%$ soybean two row.

B4=100\% sugar cane $+40 \%$ soybean two row.

with soybean was varied between treatments from 8031 to 10746 L.E $^{-1}$ fad $^{-1}$ compared with sole sugar cane (7961.60 L.E fad $\left.^{-1}\right)$.(Nazir et al., 2002 and Khippal,2016) supported our results.

Finally, it could be intercropping 100\% sugar cane with $40 \%$ soybean, one row ( 2 plant hill $\left.{ }^{-1}\right)$ of soybean in hills spaced $15 \mathrm{~cm}$ under $225 \mathrm{~kg} \mathrm{~N}^{-1} \mathrm{~d}^{-1}$ is appropriate and best under Middle Egypt conditions. 


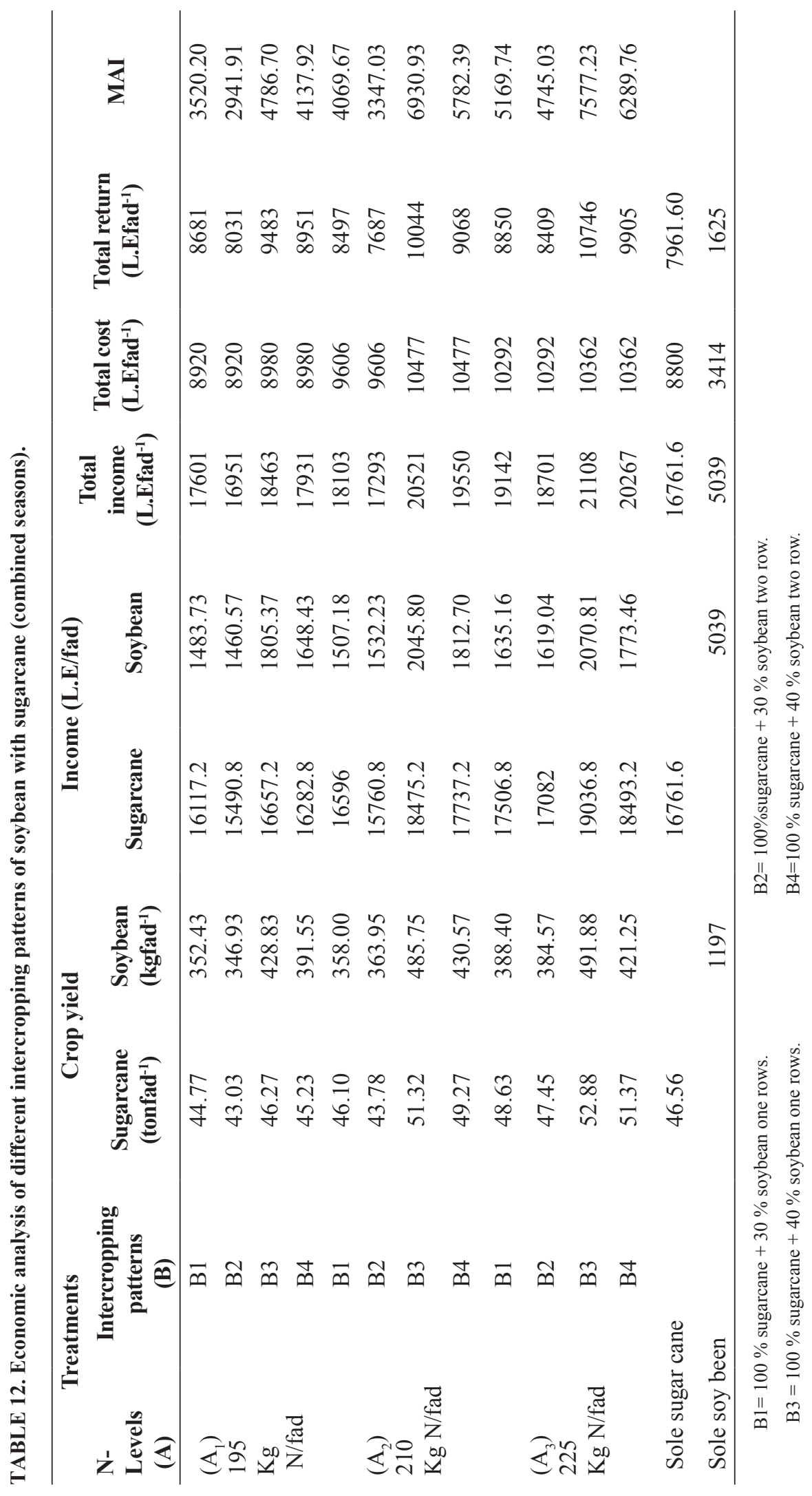

Egypt.J.Agron. Vol.39, No.2 (2017) 


\section{References}

Abdel-Wahab, T.I. and Abd El-Rahman, R.A. (2016) Response of some soybean cultivars to low light intensity under different intercropping patterns with maize. Inter. J. Applied Agric. Sci. 2(2), 21-31.

Abdul Rehman, R. Q. and Jamshaid, Q. (2014) Economic assessment of sugar cane (Soccharum officinarum L.) through intercropping. J. of Agric. Chemi. And Wnviro. 3, 24-28.

Abou-Kresha, M.A., Zohry, A.A. and Farghly, B.S. (1997) Effect of intercropping some field crops with sugar cane on yield and its components of plant cane and third ratton. Mansoura J. Agric. Sci. 22(12), 41-63.

Agriculture Statistical (2014) "Winter Crops". Agriculture Statistical and Economic Sector, 1st ed., Ministry of Agriculture and Land Reclamation, Egypt.

Agriculture Statistical (2015) "Summer \& Nile Crops". Agriculture Statistical and Economic Sector, 2nd ed., Ministry of Agriculture and Land Reclamation, Egypt.

Agriculture Statistical (2015) "Winter Crops". Agriculture Statistical and Economic Sector, 2nd ed., Ministry of Agriculture and Land Reclamation, Egypt.

A.O.A.C. (2005) "Association of Official Agricultural Chemists". Official Methods of Analysis, 26th ed. AOAC International, Washington, D.C., U.S.A.

Assey, A.A., EL-Khawaga, A.A., Zeiton, O.A. and Abdel-Hameed, A.I. (1992) Yield of intercropped corn and soybean as affected by fertilization and maize population density. Pro 5th conf. Agron. Zagazig, 13-15 Sep., 1992, 2, 546-563.

Banik, B.P. (1996) Evaluation of wheat (Triticum aestivum) and Legume intercropping under 1:1 and 2:1 row-replacement series system. J.Agron., Crop Sci. 176, 289-294.

CCSC (2013) Central Council for Sugar Crops. Annual Report, Ministry of Agriculture, Egypt.

Che Jiang-Lul, Jian-ming W.U. and Huan- zhong, S. (2011) A review on the researches on sugar canesoybean intercropping system. J. Southern Agric. 2011-08.

Dhima,K., Lithourgidis,A., Vasilakoglou, I. and Dordas, C. (2007) Competition indices of common vetch and cereal intercrops in two seeding ratio. Field Crops Res. 100, 249-256.
EL-Gergawy, A.S.S., Saif, M., EL-Amari, T.S. and ELGeddawy, I.H. (1995) Intercropping soil oil crops with spring planted sugar cane in Middle Egypt. Egypt. J. Appl. Sci. 10(5), 225-234.

Gomez, K.A. and Gomez, A.A. (1984) "Statistical Procedures for Agriculture Research". A WileyInter Science publication, John Wiley and Sons, Inc. New York, USA.

Hiebsch, C. (1978) Comparing intercrops. With monocultures. Agronomic Economic Res. On soil of tropics, 1976-1977; Annual Report. North Carolina State Univ. R-Light.

Khandgave, R-B. (2010) Agronomic management of intercropping in sugar cane and its economic implications. Proc-Int. Sugar cane Technol., Vol 27,1-4.

Khan, M.B. and Khaliq, A. (2004) Studies on intercropping summer fodders in cotton. J.Res. Sci.15, 325-331.

Khippal, A., Singh,S., Meharchand and Sheokand, R. (2016) Mechanized and profitable intercropping of legumes in autumn planted sugarcane. Legume Res. 39(3), 411-418.

Klute, A. (1986) "Methods of Soil Analysis", 2nd ed., Part 1, Physical and Mineralogical Methods. Part 2, Chemical and Microbiological Properties, Madifon, Wesconsin, USA.

Li, Z.X., Wang, J.W., Yang, W.T., Shu, Y. H., Du, Q., Liu, L.L. and Shu, L. (2011) Effects of reduced nitrogen application on the yield, quality, and economic benefit of sugar cane intercropped with soybean. Ying Yong Sheng Tai Xue Bao, 22, 713719.

Luo, S., Lingling, Y., YU, L., Ying, Z., Wenting, Y., Zhixian, L. and Jianwu, W. (2016) Effects of reduced nitrogen input on productivity and $\mathrm{N} 2 \mathrm{O}$ emissions in a sugar cane/soybean intercropping system. Europ. J. Agronomy, 81, 78-85.

Mathur, R. B. (1981) "Handbook of Cane Sugar Technology". Oxford \& IBH publishing Co.

Mc-Gilchrist, C.A. (1965) Analysis of competition on experiments biometrics.21975-985.

Nazir, M.S., Ahmad, A.J., Nawaz, S. and Bhatti, I.H. (2002) Production potential and economics of intercropping in Autumn-planted sugar cane. International J. Agric. Biology, 4(1),140-142.

Ramouthar, P.V., Rhodes, R., Wettergreen, T., Pillay, U., Jones, M.R., Van, A. and Berry, S.D. (2013) 
Intercropping in sugar cane: A practice worth pursuing. Proc. S. Sug. Technol. Ass., 86, 55-66.

Rana, N.S., Sanjay, K., Saini, S.K. and Panwar, G.S. (2006) Production potential and profitability of Autumn sugar cane based intercropping system as influenced by itercrops and row spacing. Indian J. Agron. 51, 31-33.

Satisha, G.C., Krishnappa, M. and Srikanth, K. (1996) Input of sulphur on yield and quality of sugar cane. Indian Sugar, 45(9), 397-401.

Sayed, G.J., Abdalla, M.M.F. and Metwally, A.A. (1983) Intensifying land and nutrient equivalent ratios by intercropping corn and soybean in Egypt. Soybean in tropical and subtropical cropping systems. In: Proc. Symposium, Tsukubo, Japan, pp.101-106.

Tahir, M., Malik, M.A., Tanveer, A. and Rashid, A. (2003) Competition functions of different canolabased intercropping systems. Asian J. Plant Sci. 2, 9-11.

Tang, J.C., Mboreha I.A., She, L., Liao, H., Chen HZ., Sun, ZD. and Yan, XL. (2005) Nutritional effects of soybean root architecture in a maize/soybean intercropping system. Sci. Agric. Sin. 38(6), 11961203.

Teshome, Z., Fantaye, A. and Hags, H. (2015) Effect of nitrogen and phosphorus on yield components, yield and sugar cane juice quality parameters of soybean-sugar cane intercropping at Tendaho Sugar Factory. Biochem. Physiol. 4(1),1-4.

Willey, R.W. (1979) Intercropping, its importance and research needs part 1-competition and yield advantages. Field Abst. 32, 1-10.

Xiuping, L.I., Yinghui, M.U., Yanbo, C., Xinguo, L. and Hai, N. (2013) Effect of intercropping sugar cane and soybean on growth, rhizosphere soil microbes, nitrogen and phosphorus availability. Acta Physiol.Plant, 35, 1113-1119.

Yang, J.B., Peng, D.H., Qin, L.D., Xing, Y.X., Li, Y.R. and Yang, L.T. (2015) Effect of sugar cane - soybean intercropping on cane yield, quality and economic benefit under low nitrogen condition. Editorial Board of Chinese J. of Appli. Ecology, 26(5):1426:1432. 


\section{دراسات عن تحميل فول الصويا على قصب السكر تحت مستويات مختلفة من التسميد

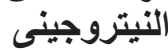

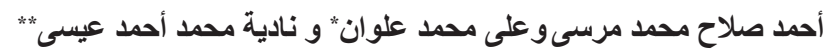

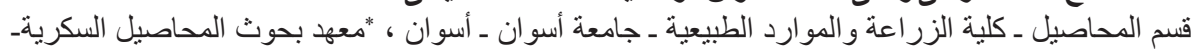

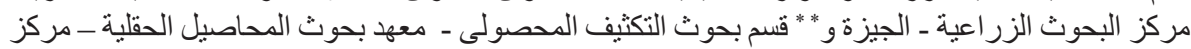

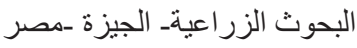

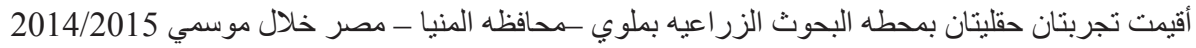

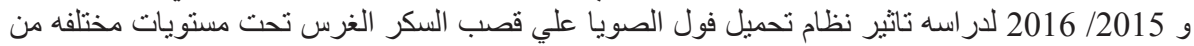

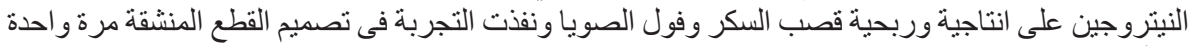

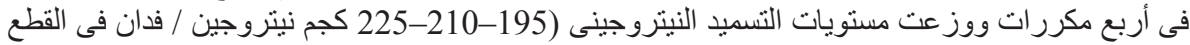

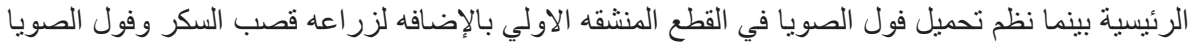

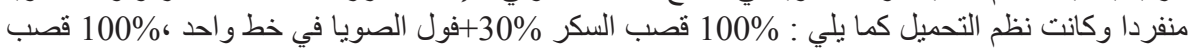

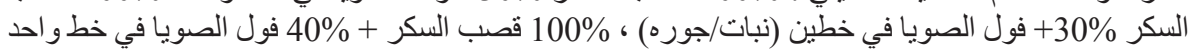
(نباتين/جوره) ، 100 \% فصب سكر + 40 \% \% فول الصويا خطين (نبات/جوره) .

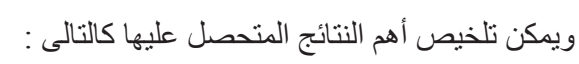

أدى زيادة معدل التسميد النتروجينى حتى 225 كجم للفدان إلى زيادة وفروق معنوية فى الدحصول ومكوناته

وكنلك صفات الجودة ومحصول السكر للفدان

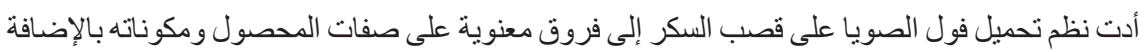

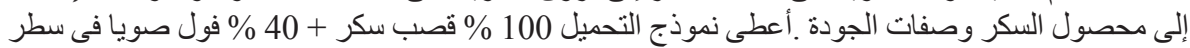
واحد (نباتين/جوره) أعطت أعلى قيم لصفات المحصول ومكوناته و السكر وصفات الجودة.

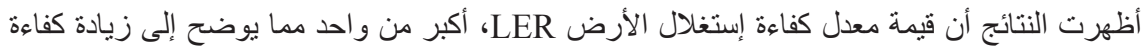

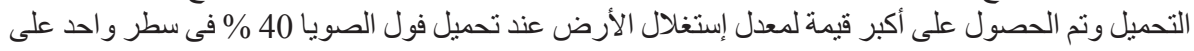
قصب السكر 100\% مع النسميد النتروجينى بمعدل 225 كجم نتروجين/فدان (1,56 ) .

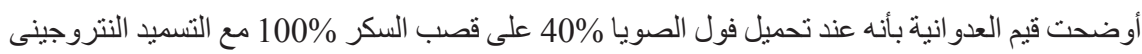

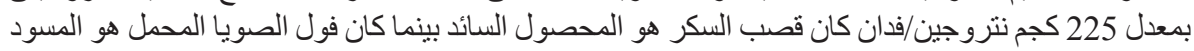
وكانت قيم المحصول الفعلى (AYL) لقصب السكر وفول الصويا إيجابية لكل نظم التحميل.

تم الحصول على أكبر عائد كلى/فدان عند زر اعة 100 \% قصب سكر +

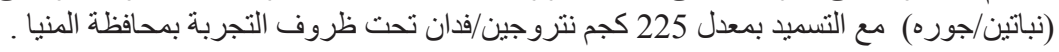

